\title{
Drug Resistance in Malaria-in a nutshell
}

\author{
Dipanjan Bhattacharjee, G. Shivaprakash* \\ Department of Pharmacology, Kasturba Medical College, Manipal University, Manipal Campus, Karnataka-576104, India.
}

\begin{tabular}{l} 
ARTICLE INFO \\
\hline Article history: \\
Received on: $19 / 11 / 2015$ \\
Revised on: $11 / 01 / 2016$ \\
Accepted on: 05/02/2016 \\
Available online: $30 / 03 / 2016$ \\
\hline Key words: \\
History, Resistance \\
mechanisms, Current status.
\end{tabular}

\begin{abstract}
One peek into the history of malaria, shows us that despite many attempts by mankind to counter the development and propagation of malaria, it has always risen back like a 'phoenix from its ashes'. This has been possible by virtue of the singular ability of the malarial parasite to mutate and evade the actions of various anti-malarial drugs. The emergence of drug resistant malarial parasites by virtue of the various molecular mechanisms, has put the authorities under the cosh and forced the scientists to start generating newer and better anti-malarial drugs. In this review, we have dwelt upon the various molecular mechanisms which have allowed the malaria parasite to develop resistance, as it can serve to educate the scientists in their effort to generate newer anti-malarials.
\end{abstract}

\section{INTRODUCTION}

The first evidence of existence of malaria has been obtained from mosquitoes preserved in amber, dating back to about 30 million years ago (Poinar, 2005). However, it is believed that malaria began to exert a major impact on the human survival with the advent of agriculture dating back to 10,000 years ago (Canali, 2008). Over many centuries, malaria has continued to exert a tremendous impact on human civilizations. As per various historical documents, malarial epidemics were believed to be responsible for bringing down the mighty Roman (Salares, 2002; Lalchhandama, 2014) and Greek civilizations (Pappas et al., 2008). The term 'malaria' too, has its origins in the $7^{\text {th }}$ centurymedieval Italy, where, mal'aria in Italian meant foul air arising from the marshes and swamps (Hempelmann and Krafts, 2013). Malaria continued to make its presence felt during the middle ages, when the coastal plains of Italy and England fell from global prominence due to malarial epidemics (Dobson, 1994). Over the years, humans have tried to counter the menace of malaria using various approaches. The earliest documentation

\footnotetext{
* Corresponding Author

Shivaprakash G., Department of Pharmacology, Kasturba Medical College, Manipal University, Manipal Campus, Karnataka - 576104, India.Email:sivag1977@gmail.com
}

of such efforts can be evidenced in the form of mosquito nets that were used by the pharaohs and garlic as a mosquito repellent by the pyramid builders. The use of artemisinin compounds can be traced back to as early as the ancient Chinese civilizations, where Qing-hao (Artemisia annua) was being used to treat malarial fever (Hsu, 2006; $\mathrm{Li}$ and $\mathrm{Wu}, 1998$ ). Till the middle ages, the treatment of malaria, commonly, had revolved around unscientific measures like bloodletting, induced vomiting, trepanning and sorcery. However, with the discovery of quinine, in the $17^{\text {th }}$ century, the fight against malaria gained wings. The scientists across the world, over these past three centuries, have been successful in unearthing various new molecules, in their bid to halt the occurrence and propagation of malaria. But the ability of the malaria parasite to adapt and evade the action of these various antimalarial drugs has led to a situation, where the world now stands on the precipice of a malarial pandemic. In light of this, it would be scientifically wise, to scrutinize the various molecular mechanisms that have allowed the malaria parasite to become resistant to the various anti-malarial drugs. Hence, in this review, we attempt to take stock of the various anti-malarials that are in play today, their mechanisms of action and the manner in which resistance has developed against these drugs in the malaria parasite and the various molecular markers of malarial resistance (table 1). Additionally, we also attempt to shed light over the present day status of each group of anti-malarial drugs. 
Table 1: Antimalarial drugs and molecular markers for drug resistance.

\begin{tabular}{ll}
\hline Drug & Marker \\
\hline \multirow{4}{*}{ Quinine } & -pfnhe: microsatellite ms4670, msR1, ms3580 \\
& -crt: M74I, N75E, K76T, H97Q, A220S, Q271E, \\
& N326S, I356T,C350S, and R371I R \\
& -mdr1: N86Y, Y184F, S1034C, N1042D, D1246Y \\
\hline \multirow{3}{*}{ Chloroquine } & -crt: M74I, N75E, K76T, H97Q, A220S, Q271E, \\
& N326S, I356T,C350S, and R371I \\
& -mdr1: N86Y, Y184F, S1034C, N1042D, D1246Y \\
& -mrp-1: Y191H, A437S \\
\hline Mefloquine & amplification of Pfmdr1 gene \\
\hline Proguanil & dhfr: A16V, S108T or N51I, C59R, I164L, S108N \\
\hline \multirow{2}{*}{ Sulfadoxine + } & -dhps: S436A/F, A437G, K540E, A581G, A613S/T \\
Pyrimethamine & -dhfr: N51I, C59R, S108N, I164L or C50R, N51I, \\
& S108N, I164L \\
\hline Atovaquone & cyt b: Y268S/N \\
\hline \multirow{3}{*}{ Artemisinin } & -Amplification of Pfmdr1 \\
& -Mutation of PfATPase6 \\
& -C580Y mutation in K13-Propeller domain with \\
& increased P13-P has been confirmed.
\end{tabular}

\section{Chloroquine and Quinine}

It was not until the $17^{\text {th }}$ century that the first medicinal products to treat malarial fever emerged in the form of cinchona tree bark. 'Fever tree bark'/ Cinchona tree bark for control of malarial fever was introduced by Jesuit missionaries during the $17^{\text {th }}$ century during their exploration in the Latin Americas, thus introducing the term 'Jesuit's bark' (Greenwood, 1992). However, it was only in the early part of $19^{\text {th }}$ century that the active principle, i.e. quinine was isolated by French chemist, Pierre Joseph Pelletier and Joseph Bienaime Caventou in 1820 (Kyle and Shampe, 1974). But, it was not until 1918, that quinine was finally commercially synthesized. Subsequently, with the synthesis of chloroquine, which belonged to the same class as quinine in 1946, the global fight against malaria gained momentum (Loeb et al., 1946). However, resistance to quinine and chloroquine was observed within a few years post its introduction, with first of such instances seen in Colombia and Cambodia-Thailand border (Payne, 1987).

By the 1980s, chloroquine resistance had reached the proportions of a global menace. The situation has presently worsened to such an extent that the genotype of malarial parasites, so obtained from the Central Americas where chloroquine was earlier believed to be effective, has also begun to exhibit features of resistance (Elbadry et al., 2013). It has been well-established that chloroquine, in its uncharged form, freely diffuses into the erythrocyte and subsequently into the digestive vacuole (DV).Inside the DV, chloroquine after undergoing protonation, is unable to penetrate the DV membrane back (Homewood et al., 1972; Yayon et al., 1984)). It then goes on to bind to the toxic hematin molecule and prevents the development of the non-toxic haemozoin crystal. The hematin interferes with parasite detoxification and damages the plasmodium membranes and leads to destruction of the parasites (Slater, 1993). Studies have shown that chloroquine sensitive parasites accumulate much more amount of chloroquine in the DV than the chloroquine resistant strains (Saliba et al., 1998). Chloroquine resistance, especially against Plasmodium falciparum, is primarily attributed to the mutation in the putative transporter located on the digestive vacuole (DV), termed as pfcrt (Plasmodium falciparum chloroquine resistance transporter) (Fidock et al., 2000). The pfcrtis a $48 \mathrm{kDa}$ protein, made up of 424 amino acids and possesses $10 \alpha$-helical transmembrane domains (TDMs) oriented inside the DV membrane and N-termini which are exposed to the cytosol (Sinha et al., 2014). It is the TDMs that are responsible for mediating the binding and translocation of substrates across the DV's membrane. The exact physiological role of the transporter is not clear, but it has been suggested this pfcrt transporter protein may be responsible for efflux of alkaloids, amine compounds, divalent cations, amino acids and peptides produced due to digestion of globin in the vacuole (Ibraheem et al., 2014). The transporter is encoded by a polymorphic pfcrt gene (Sanchez et al., 2007). Any mutation in the gene, producing a substitution/alteration in the amino acids sequence could transform its physico-chemical properties and its function. The mutant version of this transporter via an energy-dependent process has been shown to efflux chloroquine away from its heme target, thus rendering the parasite chloroquine resistant (Ibraheem et al., 2014; Sidhu et al., 2002). A few studies have revealed that multiple genetic mutations are responsible for production of mutated version of transporter. Till date, about 32 plausible mutations have been proposed, of which about a few like M74I, N75E, K76T, H97Q, A220S, Q271E,N326S, I356T, C350S and R371I (table 1) have shown correlation with chloroquine resistance (Bray et al., 2005). Among these, K76T mutation is the most prominent. However, besides K76T mutation, it has been suggested that it requires the presence of 3 other mutations to effect chloroquine resistance (Bray et al., 2005). Further, K76T mutation is primarily and completely selected only after long term exposure to chloroquine (Bray et al., 2005).

Besides the pfcrt mutations, it has been observed that pfmdr-1 (Plasmodium falciparum multi-drug resistance transporter protein-1) mutations may play a supporting role in augmenting chloroquine resistance (Haruki et al., 1994). Pf $m d r-l$ is a $\mathrm{p}$ glycoprotein transporter, located on the DV and is responsible for pumping out the xenobiotics from the cytosol (Dorsey et al., 2001). Four plausible single nucleotide polymorphisms have been noted in the pfmdr-1 gene, i.e. N86Y, Y184F, N1042D, S1034C and D1246Y (Povoa et al., 1998; Tinto et al., 2008) (table 1). The amino acid substitutions, so observed at the respective codon positions in the $p f m d r-1$ transporter, could lead to alterations in its structure and subsequently the physico-chemical properties and its potential for binding and transporting different types of xenobiotics (Bray et al., 1996). The recent studies have concluded that the presence of $p f-m d r-I$ mutant forms is not mandatory for chloroquine resistance, but may be an evolutionary response to other genetic mutations, of which pfcrt mutations seems to be the most likely culprit (Reed et al., 2000).

Additionally, chloroquine resistance in plasmodium falciparum is augmented by mutations in the pf mrp-lprotein (Plasmodium falciparum multidrug resistance associated protein). Pf $m r p-1$ refers to a DV membrane protein that is responsible for 
the influx of chloroquine in the DV (Raj et al., 2009). Two point mutations, Y191H and A437S 9 (table 1) in the gene coding for pfmrp-1may play a role in augmenting the degree of chloroquine resistance by decreasing the activity of this transporter protein (Anderson et al., 2005; Briolant et al., 2010). Investigations into chloroquine resistance among $P$. vivax have not yielded any significant results. No genetic mutation has been linked with chloroquine resistance in $P$. vivax. It is believed that there might be different mechanisms at play, which are yet to be elucidated clearly (Nomura et al., 2001). Despite the long standing menace of resistance against chloroquine, it has for long, been the drug of choice against $P$. falciparum. However, of late, chloroquine has been replaced largely by artemisinin based combination therapies as the first line of treatment. Even for P. vivax, its utility is on the decline in the wake of discovery of resistant strains. However, for $P$. ovale and $P$. malariae, it still remains the agent of choice for chemoprophylaxis and treatment.

Besides the mutations of genes pfcrt and $p f m d r-1$ on chromosomes 5 and 7 respectively, an additional mutation on the gene pfnhe-1 (Plasmodium falciparum sodium-hydrogen exchanger-1) located on chromosome 13 was implicated for increased quinine resistance (Ferdig et al., 2004). PfNHE-1, a 226 $\mathrm{kDa}$ protein with 12 predicted trans-membrane segments, located over the plasma membrane, encoded by thepfnhe-lgene is responsible for increasing the cytosolic $\mathrm{pH}$ and for compensating acidosis caused by anaerobicglycolysis (Gardner et al., 2002; Bennett et al., 2007). Three point polymorphisms at three separate codons (790 gtc/ttc, 894aat/aaa, $950 \mathrm{ggg} / \mathrm{gtg}$ ) and microsatellite variations in three different repeat sequences (table 1) on the pfnhe-1 gene are implicated in reducing quinine sensitivity in Plasmodium falciparum as they disturb the cytosolic ph and hence disrupt the action of quinine (Gardner et al., 2002). Quinine and its stereoisomer, quinidine have been treatment of choice for a long period of time for uncomplicated and drug-resistant malaria. However, with the introduction of artemesinin based therapies, quinine and its analogues are losing ground as antimalarial treatment options.

\section{Primaquine}

During the 1950s, when primaquine was introduced as an anti-malarial, there was a lot of excitement surrounding it. It exerted its action over the exo-erythrocytic stages in the liver and thus provided a radical cure. The clinical trials post the second worldwar, which was focused upon the 8-aminoquinolines, led to the development of primaquine. Primaquine became available for commercial use during the Korean war (Carson, 1984).It interrupts the disease transmission from host to mosquitoes. It is believed that primaquine can cause an interference with the functioning of ubiquinone in the respiratory chain, thus leading to an impairment of the mitochondrial activity in the parasites. Further, the production of copious amount of intracellular reactive species can lead to an increased oxidative stress within the parasitic cell (Schlesinger et al., 1988; Tekwani and Walker, 2006). Crucial lessons can be learnt from the manner of utilization of primaquine.
Despite being in use for a long period of time, resistance against this drug is clinically insignificant. Current guidelines recommend the usage of primaquine for terminal chemoprophylaxis and radical cure of $P$. vivax and $P$. ovale (relapsing) infections. It is preferably combined with a blood schizonticide, so as to target even the erythrocytic stages of the plasmodia and thus prevent the development of drug resistance.

\section{Anti-folates}

Simultaneously, the anti-folates including proguaniland sulfadoxine-pyrimethamine, introduced in 1948 (Sinha et al., 2014)and 1967 (Sinha et al., 2014) respectively, exert their antimalarial actions against both $P$. falciparum and $P$. vivax by targeting two critical enzymes, dihydrofolate reductase (DHFR) and dihydropteroate synthase (DHPS) in the folate pathway (Gregson and Plowe, 2005). Proguanil, abiguanide derivative and a product of British antimalarial research, targets DHFR. DHFR converts dihydrofolate to tetrahydrofolate. On the other hand, sulfadoxine-pyrimethamine, combined together due to their synergistic mechanism of action, target both DHFR and DHPS. DHPS is a key instrument in the synthesis of 7,8 dihydropteroate, which precedes folate synthesis. The folate pathway assumes significance as the products of this pathway, i.e. purines, pyrimidines and amino acids are indispensable for the growth and propagation of the parasite (Gregson and Plowe, 2005). Further, the stability in the differences in the amino acid sequences between the parasite and the humans allow a more parasite targeted action. Unfortunately, the effectiveness of this class of drugs diminished rapidly due to development of resistance within a year of their introduction (Sinha et al., 2014). The molecular basis of anti-folate resistance has been extensively studied and documented. A handful of point mutations at the codons leading to various amino acid sequence changes have been implicated behind anti-folate resistance (Gregson and Plowe, 2005).Resistance toproguanil was observed as early as the 1950s. As noted in table $1, \mathrm{~A} 16 \mathrm{~V}$ (alanine to valine at codon 16), S108T/N (serine to threonine at 108 codon) or N51I (asparagine to isoleucine at 51 codon), C59R (cysteine to arginine at 59 codon), I164L (Isoleucine to leucine at 164 codon) and S108N (Serine to asparagine at 108 codon) mutations have been elucidated to being responsible for production of mutant DHFR in the parasite, thus rendering proguanil ineffective (Gregson and Plowe, 2005). Similarly, resistance against pyrimethamine and sulfadoxine, noted first in themid-1970s, has been registered by virtue of production of mutant DHFR enzyme due to N51I, C59R, S108N, I164L or C50R (Cysteine to asparagine), N51I, S108N, I164L mutations (Gregson and Plowe, 2005). Further, S436A/F (serine to alanine at 436 codon), A437G (alanine to glycine at codon 437), K540E (lysine to glutamic acid at codon 540), A581G (alanine to glycine at codon 581), A613S/T (alanine to serine/threonine) point mutations have led to the production of mutant variety of DHPS (Gregson and Plowe, 2005). This combined with mutant variety of DHFR enzyme, further aggravated the resistance against sulfadoxine-pyrimethamine in the subsequent years. Due to 
widespread resistance against it, pyrimethamine-sulfadoxineis no longer recommended for the treatment of uncomplicated malaria or for chemoprophylaxis. However, it is still being recommended for the intermittent preventive treatment of malaria in pregnancy inmalarious areas. Further it is being evaluated for the same in infants (Aponte et al., 2009). Proguanil as a single agent, on one hand, has been found to be effective against chloroquine and pyrimethamine-sulfadoxine resistant strains of $P$. falciparum found in sub-Saharan Africa. However, on the other hand, it has been reported to be ineffective against multidrug-resistant strains of $P$. falciparum in Thailand and New Guinea. In the wake of widespread resistance against proguanil, it is now being utilized in combination with atovaquone, especially in areas where highly drug resistant strains of $P$. falciparum are rampant. Resistance against this combination is highly uncommon, unless the parasite specie was resistant to atovaquone in the first place.

\section{Mefloquine}

Resistance to chloroquine and quinine and quinoline group of compounds resulted in heavy human and financial losses during the Vietnam war. This led to a massive screening programme in United States of America (USA) during the 1960s, which was undertaken by the Walter Reed Army Institute of Research (WRAIR) (Peters, 1987). The end result was the emergence of a third generation quinoline methanol compound, represented as WR142490, subsequently known as Mefloquine, which received its approval as an anti-malarial drug in 1977 (Trenholme et al., 1975; Palmer et al., 1993). It's a wellestablished fact that haemoglobin after getting digested within the DV, releases a toxic free haememoiety (Kumar and Bandopadhyay, 2005). A major portion of the haeme moiety gets converted in the acidic conditions in the DV to form haemozoin or the malarial pigment (Kumar et al., 2007). The rest of the free haeme moves out into the cytosol and gets detoxified by interacting with either glutathione (Wright et al., 2001)or glutathione reductase (Campanale et al., 2003) or hydrogen peroxide (Kumar and Bandopadhyay, 2005). Mefloquine exerts its antimalarial action by inhibiting both the haemozoin formation and oxidative and glutathione dependent degradation of haeme (Foley and Tilley, 1998) as well. Studies have also shown that there might be additional modes of action involving the interaction of mefloquine with phosphatidylinositol peptides (Chevli and Fitch, 1982) as well as with volume regulated anion channels (VRAC) (Maertens et al., 2000). Mefloquine was primarily utilized to treat drug resistant falciparum malaria, especially in Thailand. However, the long plasma half-life and prolonged elimination time fostered resistance among P. falciparum. The first evidence of resistant strains emerged around 1982 in Thailand (Boudreau et al., 2011). Resistance to mefloquine has been primarily attributed to amplification in Pfmdr-1 gene (table 1), that encodes for an energy dependent p-glycoprotein pump (Pgh-1) (Karcz et al., 1993). This p-glycoprotein located on the DV is responsible for extruding out anti-malarials (Rohrbach et al., 2006). However, the exact mechanism via which pfmdr-lmediates mefloquine resistance has not yet been fully understood. The current status of mefloquine dictates that it is no longer the first line of treatment in most of the clinical scenarios. Further, in malaria endemic areas, where multi-drug resistant strains are rampant, combining mefloquine with artemesinin has proven to be a very effective strategy in controlling and preventing malarial infections.

\section{Atovaquone}

In the face of mounting resistance against anti-malarial drugs, there was an urgent necessity of newer drugs for treatment and chemoprophylaxis for malaria during the 1990s (Mihous, 2001). The search for newer drugs with new cellular targets resulted in the emergence of atovaquone, a hydroxynaphthoquinone derivative. This drug is active against asexual stages and even the liver stages of $P$. falciparum, but not so against $P$. vivax. Atovaquone specifically inhibits cytochrome bcl (cytbcl) complex, an important cog in the electron transport system (Vaidya and Mather, 2009). The mitochondrial electron transport system in $P$. falciparum is tasked with the purpose of regenerating ubiquinone, which in turn serves as an electron acceptor for parasitic dihydroorotate dehydrogenase, an enzyme responsible for pyrimidine biosynthesis in the parasite (Painter et al., 2007). However, utilization of atovaquone as a monotherapy, leads to development of resistance very easily. The mechanism of resistance involves a point mutation at codon 268 of $c y t b$ gene (table 1) where tyrosine gets replaced by serine, cysteine or asparagine (Kessl et al., 2007). Another point of note isthe existence of an additional mutation at position 266 (Kesslet al., 2005), where Proline (P) is substituted by Threonine (T) in few of the patients. In view of the high and frequent cases of resistance seen against the drug, it is believed among the scientists that there might be additional mutations within the ubiquinone reduction site that might be at play. Presently, atovaquone is combined with proguanil in view of the synergistic mode of actions as a combination therapy for malaria chemoprophylaxis in adults and children $\geq 11 \mathrm{~kg}$ and for treatment of uncomplicated $P$. falciparum malaria in adults and children $\geq 5 \mathrm{~kg}$.

\section{Artemisinin and its derivatives}

In view of the alarming emergence of chloroquine resistance among malarial parasites, Project 523 was initiated in 1967 by the Chinese government. This ultimately yielded in artemisinin and its derivatives, artesunate and artemether, which are now the preferred drugs in all chloroquine resistant areas (Miller and $\mathrm{Su}$, 2011).Resistance against artemisinin, a long existing enigma in the treatment of malaria, has also been reported since 1980s (Sinha et al., 2014). The menace of artemisinin resistance, limited initially to a few sporadic cases in the greater Mekong region, has now assumed significant proportions (Sanders et al., 2014; Bosman et al., 2014). Artemisinin, a sesquiterpene lactone endoperoxide contains a peroxide bridge which is responsible for its enigmatic mode of action. One line of thought dictates that the cleavage of the peroxide bridge in the presence of ferrous ions gives rise to highly reactive free radicals, which in 
turn lead to the parasite's death (Meshnick et al., 1991). A second line of thought proposes that an interaction between artemisinin and PfATP6 is essential to the parasitic death (Eckstein-Ludwig et al., 2003). PfATP6 is the only SERCA-type (Sarcoplasma endoplasmic reticulum calcium channel) $\mathrm{Ca} 21$-ATPase present in the malaria parasite. Physiologically, PfATP6 serves the same purpose as any mammalian SERCA. Studies have illustrated that artemisinin exerts its action via PfATP6.Inhibition of this enzyme subsequently inhibits the action of artemisinin. Once inside the parasite cell, artemisinin gets activated by free iron neighbouring PfATP6 in the endoplasmic reticulum. In the presence of ferrous ions in the $\mathrm{DV}$, the cleavage of the peroxide bridge occurs, producing highly reactive free radicals and ultimately leading to the parasite's death (Ridley, 2003). There is no established mechanism behind the development of artemisinin resistance. However, ongoing research has identified mutations in the genes encoding for PfATP6 (Sinha et al., 2014) and amplification in the Pfmdr-1 (Sinha et al., 2014) encoding gene to being responsible for artemisinin resistance. Further among the recent advances made, it has been observed that point mutation, i.e.C580Y in the propeller region of kelch motif containing gene or K13 is the prime reason for artemisinin resistance observed in the greater Mekong region. The C580Y mutation reduces polyubiquitination of $P$. falciparum phosphatidylinositol-3-kinase (PfPI3K), which in turn limits the proteolysis of $P f P I 3 K$ leading to an increase in its level along with the level of its lipid product phosphatidylinositol3-phosphate $(P I 3 P)$. Thus along with the K13 mutation marker, PI3Plevels can also be predictive of artemisinin resistance (Ghorbal et al., 2014; Straimer et al., 2015; Mok et al., 2015; Ariey et al., 2014). Despite their rapid activity and high potency, even in the face of multi-drug resistant malarial parasites, the artemisininsare not used as a monotherapy due to their limited ability to eradicate the infection into to. Their short plasma halflife limits its utility as a chemo-prophylactic agent and also leads to more chances of treatment failures. However, when artemisinins are combined with other antimalarials/ACT (Artemisinin combination therapy) partner drugs, they lead to sustained antimalarial action. Hence ACT now form the first line of treatment for any form of malaria, especially in case of severe malaria. The current regimens employ lumefantrine, mefloquine, amodiaquine and piperaquine as the accompanying drugs to artemisinin in the combination regimens.

\section{CONCLUSION}

The irrational and extensive utilization of anti-malarials leading to a sustained and increased drug pressure combined with the singular ability of the parasite to mutate and adapt, has facilitated the development and propagation of resistance in malarial parasites. Resistance has been recorded against almost every anti-malarial drug that is available in the market today. Hence, identifying new targets and developing new molecules that act upon these targets is the need of the hour. Presently the antimalarial drug pipeline seems to be drying up. However, this can be rectified by a concerted effort by the authorities, financial aid providers and the scientific community coming together to help control, if not eliminate the menace of drug resistance in malaria.

\section{REFERENCES}

Anderson TJC, Nair S, Qin H, Singlam S, Brockman A, Paiphun L, Nosten F. Are transporter genes other than the chloroquine resistance locus (pfcrt) and multidrug resistance gene (pfmdr) associated with antimalarial drug resistance? Antimicrobial Agents and Chemotherapy, 2005; 49 (6):2180-2188.

Aponte JJ, Schellenberg D, Egan A, Breckenridge A, Carneiro I, Critchley J, Danquah I, Dodoo A, Kobbe R, Lell B, May J, Premji Z, Sanz S, Sevene E,Soulaymani-Becheikh R, Winstanley P, Adjei S, Anemana S, Chandramohan D, Issifou S, Mockenhaupt F, OwusuAgyeiS, Greenwood B, Grobusch MP, Kremsner PG, Macete E, Mshinda H, Newman RD, Slutsker L, Tanner M, Alonso P, Menendez C. Efficacy and safety of intermittent preventive treatment with sulfadoxinepyrimethamine for malaria in African infants: A pooled analysis of six randomised, placebo-controlled trials. Lancet, 2009; 374:1533-1542.

Ariey F, Witkowski B, Amaratunga C, Beghain J, Langlois AC, Khim N, Kim S, Duru V, Bouchier C, Ma L, Lim P, Leang R, Duong S, SrengS,Suon S, Chuor CM, Bout DM, Ménard S, Rogers WO, Genton B, Fandeur T, Miotto O, Ringwald P, Le Bras J, BerryA, Barale JC, Fairhurst RM, Benoit-Vical F, Mercereau-Puijalon O, Ménard D. A molecular marker of artemisinin-resistant Plasmodium falciparum malaria. Nature. 2014; 505:50-55.

Boudreau EL, Webster HK, Pavanand K, Thosingha L. Type II mefloquine resistance in Thailand. Lancet, 1982; 2 (8311):13351335 .

Bray PG, Hawley SR, Mungthin M, Ward SA. Physicochemical properties correlated with drug resistance and the reversal of drug resistance in Plasmodium falciparum. Molecular Pharmacology, 1996; 50 (6):1559-1566.

Bray PG, Martin RE, Tilley L, Ward SA, Kirk K, Fidock DA. Defining the role of PfCRT in Plasmodium falciparum chloroquine resistance. Molecular Microbiology, 2005; 56:323-333.

Bennett TN, Patel J, Ferdig MT, Roepe PD. Plasmodium falciparum $\mathrm{Na}+/ \mathrm{H}+$ exchanger activity and quinine resistance. Mol Biochem Parasitol, 2007; 153:48-58.

Briolant S, Henry M, Oeuvray C, Amalvict R, Baret E, Didillon E, Rogier C, Pradines B. Absence of association between piperaquine in vitro responses and polymorphisms in the pfcrt, pfmdr1, pfmrp, and pfnhe genes in Plasmodium falciparum. Antimicrobial Agents and Chemotherapy, 2010; 54 (9):3537-3544.

Bosman P, Strassijns J, Nackers F, Canier L, Kim N, Khim S, Alipon SC, Chuor Char M, Chea N, Dysoley L, Van den Bergh R, Etienne W, De Smet M, Ménard D, KindermansJM. Plasmodium prevalence and artemisinin-resistant falciparum malaria in Preah Vihear Province, Cambodia: a cross-sectional population-based study. Malaria Journal, 2014; 13: 394.

Chevli R, Fitch CD. The antimalarial drug mefloquine binds to membrane phospholipids. Antimicrob. Agents Chemother, 1982; 21:581586.

Carson PE. 1984. 8-Aminoquinolines. In: Peters W, Richards WHG , eds. Antimalarial drugs. II. Current antimalarials and new drug developments. Berlin: Springer-Verlagpublishing 83-121.

Campanale $\mathrm{N}$, Nickel C, Daubenberger CA, Wehlan DA, Gorman JJ, Klonis N, Becker K, Tilley L. Identification and characterization of heme-interacting proteins in the malaria parasite, Plasmodium falciparum. J BiolChem, 2003; 278:27354- 27361.

Canali S. Researches on thalassemia and malaria in Italy and the origins of the "Haldane hypothesis. Med Secoli, 2008; 20 (3):827-46.

Dobson MJ. Malaria in England: a geographical and historical perspective. Parassitologia, 1994; 36 (1-2):35-60.

Dorsey G, Kamya MR, Singh A, Rosenthal PJ. Polymorphisms in the Plasmodium falciparum pfort and pfmdr- 1 genes and clinical 
response to chloroquine in Kampala, Uganda. Journal of Infectious Diseases, 2001; 183 (9):1417- 1420.

Eckstein-Ludwig U, Webb RJ, Van Goethem ID, East JM, Lee AG, Kimura M, et al. Artemisinins target the SERCA of Plasmodium falciparum. Nature, 2003; 424; 957-961.

Elbadry MA, Existe A, Victor YS, Memnon G, Fukuda M, Dame JB, Yowell CA, Okech BA. Survey of Plasmodium falciparum multidrug resistance-1 and chloroquine resistance transporter alleles in Haiti. Malaria Journal, 2013; 12:426.

Foley M, Tilley L. Quinoline Antimalarials: Mechanisms of Action and Resistance and Prospects for New Agents. Pharmacol Ther, 1998; 79:55-87.

Fidock DA, Nomura T, Talley AK, Cooper RA, Dzekunov SM, Ferdig MT, Ursos LM, Sidhu AB, Naudé B, Deitsch KW, Su XZ, Wootton JC, Roepe PD, Wellems TE. Mutations in the P. falciparum digestive vacuole transmembrane protein PfCRT and evidence for their role in chloroquine resistance. Mol Cell, 2000; 6:861-871.

Ferdig MT, Cooper RA, Mu J, Deng B, Joy DA, Su XZ, Wellems TE. Dissecting the loci of low-level quinine resistance in malaria parasites. Mol Microbiol, 2004;52:985-997.

Grassi B, Bignami A, Bastianelli G. Ulteriorericerchesulciclodeiparassitimalariciumani $\quad$ sulcorpo del zanzarone. Accad Lincei, 1899; 8:21-28.

Greenwood D. The quinine connection. J Antimicrob Chemother, 1992; 30 (4):417-27

Gardner MJ, Shallom SJ, Carlton JM, Salzberg SL, Nene V, Shoaibi A, Ciecko A, Lynn J, Rizzo M, Weaver B, Jarrahi B, Brenner M, Parvizi B, Tallon L, Moazzez A, Granger D, Fujii C, Hansen C, Pederson J, Feldblyum T, Peterson J, Suh B, Angiuoli S, Pertea M, Allen J, Selengut J, White O, Cummings LM,Smith HO, Adams MD, Venter JC, Carucci DJ, Hoffman SL, Fraser CM. Sequence of Plasmodium falciparum chromosomes 2, 10, 11 and 14. Nature, 2002; 419:531-534

Gregson A, Plowe CV. Mechanisms of resistance of malaria parasites to antifolates. Pharmacological Reviews, 2005; 57:117-145.

Ghorbal M, Gorman M, Macpherson CR, Martins RM, Scherf A, Lopez-Rubio JJ. Genome editing in the human malaria parasite Plasmodium falciparum using the CRISPR-Cas9 system. Nat Biotechnol, 2014; 32:819-21.

Homewood CA, Warhurst DC, Peters W, Baggaley VC. Lysosomes, $\mathrm{pH}$ and the anti-malarial action of chloroquine. Nature, 1972; 235:50-52.

Haruki K, Bray PG, Ward SA, Hommel M, Ritchie GY. Chloroquine resistance of Plasmodium falciparum: further evidence for a lack of association with mutations of the pfmdr1 gene. Transactions of the Royal Society of Tropical Medicine and Hygiene, 1994; 88 (6):694

Hsu E. Reflections on the 'discovery' of the antimalarial qinghao. Br J Clin Pharmacol, 2006;61 (6):666-70.

Hempelmann E, Krafts K. Bad air, amulets and mosquitoes: 2,000 years of changing perspectives on malaria. Malar J, 2013; 12 (1): 213

Ibraheem ZO, Majid RA, Noor SM, Sedik HM, Basir R. Role of Different Pf crt and Pf mdr-1 Mutations in Conferring Resistance to Antimalaria Drugs in Plasmodium falciparum. Malaria Research and Treatment, 2014; 2014:950424 (article ID). 229 (4):462.

Kyle RA, Shampe MA. Discoverers of quinine. JAMA, 1974;

Karcz SR, Galatis D, Cowman AF. Nucleotide binding properties of a P-glycoprotein homologue from Plasmodium falciparum. Mol Biochem Parasitol, 1993a; 58:269-276.

Kho WG, Jang JY, Hong ST, Lee HW, Lee WJ, Lee JS. Border malaria characters of reemergingvivax malaria in the Republic of Korea. Korean J Parasitol, 1999; 37:71-76.

Kessl JJ, Ha KH, Merritt AK, Lange BB, Hill P, Meunier B, Trumpower BL. Cytochrome $\mathrm{b}$ mutations that modify the ubiquinolbinding pocket of the cytochrome bc1 complex and confer anti-malarial drug resistance in Saccharomyces cerevisiae. J BiolChem, 2005; 280:17142-17148.
Kumar S, Bandyopadhyay U. Free heme toxicity and its detoxification systems in human. ToxicolLett, 2005; 157:175-188.

Kessl JJ, Meshnick SR, Trumpower BL. Modeling the molecular basis of atovaquone resistance in parasites and pathogenic fungi. Trends Parasitol,2007; 23:494-501.

Kumar S, Guha M, Choubet V, Maity P, Bandyopadhyay U. Antimalarial drugs inhibiting hemozoin ( $\beta$-hematin) formation: a mechanistic update. Life sciences, 2007; 80:813-828.

Loeb RF, Clark WM, Coatney GR, Coggeshall LT, Dieuaide FR, Dochez AR, et al. Activity of a new antimalarial agent, chloroquine (SN 7618). J Am Med Assoc, 1946; 130 (16):1069-1070.

Looareesuwan S, Wilairatana P, Krudsood S, Treeprasertsuk S, Singhasivanon P, Bussaratid V, Chokejindachai W, Virayavejakul P, Chalermrut K, Walsh DS, White NJ. Primaquine-tolerant vivax malaria in Thailand. Annals of Tropical Medicine \& Parasitology, 1997; 91:939-943. Li Y, Wu YL. How Chinese scientists discovered qinghaosu (artemisinin) and developed its derivatives? What are the future perspectives? Med Trop, 1998; 58 (3 Suppl):9-12.

Lalchhandama K. The making of modern malariology: from miasma to mosquito-malaria theory. Science Vision, 2014; 14 (1):3-17.

Mouchet J, Nadire-Galliot M, Gay F, Poman JP, Lepelletier L, Claustre J, Bellony S. Malaria in Guiana. II. The characteristics of different foci and antimalarial control. Bull SocPatholExotFiliales, 1989; 82:393-405

Meshnick SR, Thomas A, Ranz A, Xu CM, Pan HZ Artemisinin (qinghaosu): the role of intracellularhemin in its mechanism of antimalarial action. Molecular and biochemical parasitology, 1991; 49:181-189.

Murphy GS, Basri H, Purnomo, Andersen EM, Bangs MJ, Gorden J, Sorensen K, Mount DL, Lal AA, Purwokusumo AR, Harjosuwarno S, Hoffman SL. Vivax malaria resistant to treatment and prophylaxis with chloroquine. Lancet. 1993; 341:96-100.

Maertens C, Wie L, Droogmans G, Nilius B. Inhibition of volume-regulated and calcium activated chloride channels by antimalarial mefloquine. J Pharm ExpTher, 2000; 295:29-36.

Milhous WK. Development of new drugs for chemoprophylaxis of malaria. Med Trop (Mars), 2001; 61:48-50.

Miller LH, Su X. Artemisinin: Discovery from the Chinese Herbal Garden. Cell, 2011; 146 (6):855-858.

Mok S, Ashley EA, Ferreira PE, Zhu L, Lin Z, Yeo T, , Chotivanich K, Imwong M, Pukrittayakamee S, Dhorda M, Nguon C, Lim P, AmaratungaC,Suon S, Hien TT, Htut Y, Faiz MA, Onyamboko MA, Mayxay M, Newton PN, Tripura R, Woodrow CJ, Miotto O, Kwiatkowski DP, NostenF,Day NP, Preiser PR, White NJ, Dondorp AM, Fairhurst RM, Bozdech Z. Population transcriptomics of human malaria parasites reveals themechanism of artemisinin resistance. Science, 2015;347: 431-35.

Nomura T, Carlton JM, Baird JK, del Portillo HA, Fryauff DJ, D. Rathore, , Fidock DA, Su X, Collins WE, McCutchan TF, Wootton JC, Wellems TE. Evidence for different mechanisms of chloroquine resistance in 2 Plasmodium species that cause human malaria. J Infect Dis, $2001 ; 183: 1653-1661$

Noedl H, Se Y, Schaecher K, Smith BL, Socheat D, Fukuda MM. Evidence of Artemisinin-Resistant Malaria in Western Cambodia.N Engl J Med, 2008; 359:2619-2620.

Paul BK. Malaria in Bangladesh. Geogr Rev, 1984; 74:63-75.

Packard RM. Agricultural development, migrant labor and the resurgence of malaria in Swaziland. SocSci Med, 1986; 22 (8):861-7.

Payne D. Spread of chloroquine resistance in Plasmodium falciparum. Parasitol, Today (Regul. Ed.) 1987; 3 (8):241-6.

Peters W. 1987. Chemotherapy and Drug Resistance in Malaria. London, England: Academic Press.

Palmer KJ, Holliday SM, Brogden RN. Mefloquine. A review of its antimalarial activity, pharmacokinetic properties and therapeutic efficacy. Drugs, 1993; 45:430- 475.

Povoa MM, Adagu IS, Oliveira SG, Machado RLD, Miles MA, Warhurst DC. Pfmdr1 (Asn)1042 (ASp) and (Asp)1246 (Tyr) polymorphisms, thought to be associated with chloroquine resistance, are 
present in chloroquine-resistant and -sensitive Brazilian field isolates of Plasmodium falciparum. Experimental Parasitology, 1998; 88 (1):64-68.

Philip Stevens. 2004. Disease of Poverty and the 10/90 Gap. International Policy Network. London, Great Britain: Hanway Print Centre.

Poinar G. Plasmodium dominicana n. sp. (Plasmodiidae: Haemospororida) from Tertiary Dominican amber. SystParasitol, 2005; 61 (1):47-52.

Painter HJ, Morrisey JM, Mather MW, Vaidya AB. Specific role of mitochondrial electron transport in blood-stage Plasmodium falciparum. Nature, 2007; 446:88-91.

Pappas G, Kiriaze IJ, Falagas ME. Insights into infectious disease in the era of Hippocrates. Int J Infect Dis, 2008; 12 (4):347-50.

Reed MB, Saliba KJ, Caruana SR, Kirk K, Cowman AF. Pgh1 modulates sensitivity and resistance to multiple antimalarials in Plasmodium falciparum. Nature, 2000; 403 (6772):906-909.

Ridley RG. Malaria: to kill a parasite. Nature, 2003; 424:887889

Rohrbach P, Sanchez CP, Hayton K, Friedrich O, Patel J, Sidhu AB, Ferdig MT, Fidock DA, Lanzer M. Genetic linkage of pfmdr1 with food vacuolar solute import in Plasmodium falciparum. EMBO J, 2006; 25:3000-3011.

Raj DK, Mu J, Jiang H, Kabat J, Singh S, Sullivan M, Fay MP,McCutchan TF,Su X. Disruption of a Plasmodium falciparum multidrug resistance-associated protein (PfMRP) alters its fitness and transport of antimalarial drugs and glutathione. Journal of Biological Chemistry, 2009; 284 (12):7687-7696.

Schlesinger PH, Krogstad DJ, Herwaldt BL. Antimalarial agents: mechanisms of action. Antimicrob Agents Chemother, 1988; 32 (6):793-798.

Slater AF. Chloroquine: mechanism of drug action and resistance in Plasmodium falciparum. PharmacolTher,1993; 57:203-235.

Saliba KJ, Folb PI, Smith PJ. Role for the plasmodium falciparum digestive vacuole in chloroquine resistence. Biochem Pharmacol, 1998; 56:313-320.

Sallares R. 2002. Malaria and Rome: a history of malaria in ancient Italy. London, England: Oxford University Press.

Sidhu ABS, Verdier-Pinard D, Fidock DA. Chloroquine resistance in Plasmodium falciparum malaria parasites conferred by pfcrt mutations. Science, 2002; 298 (5591):210-213.

Sanchez CP, Rohrbach P, McLean JE, Fidock DA, Stein WD, Lanzer M.Differences in trans stimulated chloroquine efflux kinetics are linked to PfCRT in Plasmodium falciparum. MolMicrobiol, 2007;64:407420 .

Sinha S, Medhi B, Sehgal R. Challenges of drug-resistant malaria. Parasite, 2014; 21:61.

Saunders DL, Vanachayangkul P, Lon C. Dihydroartemisininpiperaquine failure in Cambodia. New Engl J Med, 2014; 371:484-485.
Straimer J, Gnadig NF, Witkowski B, Amaratunga C, Duru V, Ramadani AP, Dacheux
M, Khim
$\mathrm{N}$, Zhang
L, Lam
S, Gregory

PD, UrnovFD,Mercereau-Puijalon O, Benoit-VicalF, Fairhurst RM, Ménard D, Fidock DA. K13 propeller mutations confer artemisinin resistance in Plasmodium falciparum clinical isolates. Science, 2015; 347:428-31.

Trenholme CM, Williams RL, Desjardins RE, Frischer H, Carson PE, Rieckmann KH, Canfield CJ. Mefloquine (WR 142,490) in the treatment of human malaria. Science, 1975; 190:792-794.

Tekwani BL, Walker LA. 8-Aminoquinolines: future role as antiprotozoal drugs. Curr Opin Infect Dis, 2006; 19 (6):623-631.

Tinto H, Guekoun L, Zongo I, Guiguemde RT, ' D'Alessandro U, Ouedraogo JB. Chloroquine-resistance ' molecular markers (Pfcrt T76 and Pfmdr-1 Y86) and amodiaquine resistance in Burkina Faso. Tropical Medicine and International Health, 2008; 13 (2):238-240.

Tun KM, Imwong M, Lwin KM, Win AA, Hlaing TM, Hlaing T, Kyaw MP, Plewes K, Faiz MA, Dhorda M, Cheah PY, Pukrittayakamee S, Ashley EA, Anderson TJ, Nair S, McDew-White M, Flegg JA, Grist EP, Guerin P, Maude RJ, Smithuis F, Dondorp AM, Day NP, Nosten F, White NJ, Woodrow CJ. Spread of artemisinin-resistant Plasmodium falciparum in Myanmar: a cross-sectional survey of the K13 molecular marker. Lancet Infectious Diseases, 2015; 15 (4):415-421.

Vaidya $\mathrm{AB}$, Mather MW. Mitochondrial evolution and functions in malaria parasites. Annu Rev Microbiol, 2009; 63:249-267.

World Health Organization. 2001. Antimalarial drug combination therapy: report of a WHO technical consultation.Geneva, Switzerland: World Health Organization Press.

Wright CW, Addac-Kyereme J, Breen AG, Brown JE, Cox MF, Croft SL, Gökçek Y, Kendrick H, Phillips RM, Pollet PL. Synthesis and evaluation of cryptolepine analogues for their potential as new antimalarial agents. J Med Chem, 2001; 44:3187- 3194.

World Health Organisation. 2015. Available from: http://www.who.int/mediacentre/factsheets/fs094/en. [ Reviewed April 2015].

Yayon A, Cabantchik ZI, Ginsburg H. Identification of the acidic compartment of Plasmodium falciparum-infected human erythrocytes as the target of the antimalarial drug chloroquine. EMBO J, $1984 ; 3: 2695-2700$.

\section{How to cite this article:}

Bhattacharjee D., Shivaprakash G. Drug Resistance in Malaria - in a nutshell. J App Pharm Sci, 2016; 6 (03): 137-143. 